\title{
Integrated approach to foreign language teaching: sustainable development of higher education
}

\author{
Irina Pirozhkova* \\ Ural State University of Economics, 8 Marta Str., 62, 620144 Ekaterinburg, Russia
}

\begin{abstract}
The article discusses development of an integrated approach of teaching English to students majoring in Management and IT technologies in the Ural State University of Economics and describes the experience of its implementation. Current trends in education require the use of nontraditional means in class to activate students' potential and help them master the necessary competences. This integrated approach meets the requirements of the educational standard and is based on the survey among students held to reveal their needs and interests in a foreign language. It exceeds the boundaries of the textbook (which is still the basis for learning) and includes participation in multi-university projects and scientific conferences, use of on-line resources and creative tasks.
\end{abstract}

\section{Introduction}

Changes in the social reality stimulate different spheres of life towards introduction of new forms, methods and trajectories. Education is affected by these changes as well, the need for its development not only in theory, but also in practice has become especially obvious. The problem that foreign language teachers face is the abundance of different methods introduced in foreign language teaching and the necessity to choose those that would meet students' needs best. Russian education shows a tendency to standardization of educational programs and learning outcomes. According to the Federal State Educational Standards in Higher Education, university graduates of Bachelor programs in IT and Management should possess the following competences related to a foreign language: communication in oral and written forms in Russian and foreign languages for interpersonal and intercultural cooperation in everyday and official communication; the ability to work in a team being tolerant to social, ethic, religious and cultural differences; and the ability of selforganization and self-education. The purpose of the study is to justify the need for a new approach to teaching English; to update the content of teaching with regard to competence development and student-centered approach; to introduce modern technologies in English classes on a regular basis; and to provide methodological support to young university teachers.

\footnotetext{
* Corresponding author: irene22@live.ru
} 


\section{Materials and methods}

\subsection{Research Methods}

The study employs general scientific methods: it analyzes and compares different views on foreign language teaching to non-linguistic students, makes general conclusions, describes implementation process of a new methodology and interprets the results obtained. Empirical methods include pedagogical observation, linguodidactic experiment and comparison of results.

\subsection{Materials}

Good knowledge of English has become a demand for employment in different spheres, "modern business requires a technical university graduate to be a specialist possessing not only knowledge necessary for performance of engineering duties in development, production, research and usage of production objects, but also the skills for professional and intercultural communication in a foreign language" [1]. It is obvious that "in the reality of global economic processes, integration of different kinds of activities within one profession is quite possible, for instance, participation of specialists in international research projects and the desire to promote their professional skills, which requires good knowledge of a foreign language" [2]. However many research results show lack of English professional communication skills among students of different specialties (engineers, economists, managers, linguists, etc.) [3, 4]. The need for perfection of learning and teaching English has led to research in the sphere of methods of teaching.

Today pedagogy appeals to student-centered education more and more often. The concept of "person-centered approach" was introduced by the American psychologist Carl Rogers, according to whom a person is the center of a constantly changing world of experiences, the sources for the changes are incorporated in the human and serve as the stimulus for personal development. It was adopted by different sciences, pedagogy in particular, and the model of "student-centered approach" was introduced in teaching. The main goal of education, in Roger's view, is to help students activate their inner motivation and resources to solve educational problems. The learning content should be filled with tasks relevant for the students and reflecting their experiences and satisfying their needs [5]. In this research the model of "student-centered approach" has become especially relevant, as we believe that adult learners need an opportunity to express their view on the problems relevant for them and not for their teachers or textbook authors. The students are free to interpret the learning tasks and to use language means suitable for their level of English and the situation. Thus, teaching English is not a unified plan, the same to all the students, but rather a process suitable for each student in class and resulting in competence development, allocated by the Federal Standard.

\section{Results and discussion}

\subsection{The search for the right approach}

The main reasons that forced us to search for a new method of teaching English in the Ural State University of Economics (further referred to as USUE) are the following: 1) mixed abilities groups - within one academic group there are students just beginning to learn English and those who show quite good results (Intermediate level and above); 2) different personal goals - students of the same specialty want to have quite different professions, for 
instance in the group of "Managers" some students learn English to work in international companies, while others just want to read English books in the original; 3) different interests - even though all IT students are interested in computers, they all have their hobbies that may influence their career, we need to give each student an opportunity to share their interests; 4) different backgrounds - students come from different parts of the country (and even the world) and they are used to different teaching styles (traditional, communicative or creative); 5) mixed nationality groups - the university has many foreign students from distant countries (Senegal, Colombia, Libya, Italy, China, Turkey, etc.).

To reveal the students' needs and interests in the foreign language (English) we made a survey among the first year students in 2019. Thirty two students took part in this survey and we got the following results (Table 1).

Table 1. Questionnaire results to reveal students' interests in learning English

\begin{tabular}{|c|c|c|c|c|c|}
\hline \multicolumn{6}{|c|}{ What is the most efficient method of teaching English for you? } \\
\hline $\begin{array}{l}\text { Communicative- } \\
75 \%\end{array}$ & \multicolumn{2}{|c|}{$\begin{array}{l}\text { Project-based - } \\
18.75 \%\end{array}$} & \multicolumn{3}{|c|}{ Traditional $-6.25 \%$} \\
\hline \multicolumn{6}{|c|}{ What are your problems in learning English? (several answers were possible) } \\
\hline $\begin{array}{l}\text { Can't speak freely - } \\
56.2 \%\end{array}$ & \multicolumn{2}{|c|}{ Poor grammar $-50 \%$} & $\begin{array}{lc}\text { Lack } & \text { of } \\
\text { words } & - \\
40.6 \% & \\
\end{array}$ & $\begin{array}{ll}\text { Poor writing } \\
\text { skills } \\
37.5 \%\end{array}$ & $\begin{array}{l}\text { Fear to speak } \\
-28 \%\end{array}$ \\
\hline \multicolumn{6}{|c|}{ What skills are the most important to you? (several answers were possible) } \\
\hline $\begin{array}{l}\text { Communication - } \\
65.6 \%\end{array}$ & $\begin{array}{l}\text { Reading } \\
-53 \%\end{array}$ & \begin{tabular}{|l|} 
Business \\
writing-- \\
$37.5 \%$
\end{tabular} & $\begin{array}{l}\text { Translation } \\
\text { skills } \\
34.4 \%\end{array}$ & \begin{tabular}{lr}
\multicolumn{2}{|l|}{ Professional } \\
use & of \\
English & - \\
$34.4 \%$ & \\
\end{tabular} & $\begin{array}{l}\text { Understanding } \\
\text { foreign speech } \\
-31.2 \%\end{array}$ \\
\hline \multicolumn{6}{|c|}{ 4. What atmosphere in class do you prefer? } \\
\hline $\begin{array}{l}\text { Calm, quiet, } \\
\text { predictable }-47.6 \%\end{array}$ & \multicolumn{2}{|c|}{$\begin{array}{l}\text { Competitive, } \\
\text { stimulating }-26.2 \%\end{array}$} & \multicolumn{3}{|c|}{ Imitating professional activity $-26.2 \%$} \\
\hline \multicolumn{6}{|c|}{ What atmosphere in class is the most productive? } \\
\hline $\begin{array}{l}\text { Competitive, } \\
\text { stimulating }-46.8 \\
\%\end{array}$ & \multicolumn{2}{|c|}{$\begin{array}{l}\text { Imitating professional } \\
\text { activity }-31.2 \%\end{array}$} & \multicolumn{3}{|c|}{ Calm, quiet, predictable $-22 \%$} \\
\hline \multicolumn{6}{|c|}{ What outcome of learning English do you expect? } \\
\hline $\begin{array}{l}\text { Free } \\
\text { communication in } \\
\text { English-56.2\% }\end{array}$ & \multicolumn{2}{|c|}{$\begin{array}{l}\text { Prof. communication } \\
\text { in English }-22 \%\end{array}$} & $\begin{array}{l}\text { Better } \\
\text { vocabulary } \\
-6.2 \%\end{array}$ & $\begin{array}{l}\text { Better } \\
\text { grammar } \\
6.2 \%\end{array}$ & Others $-9.3 \%$ \\
\hline
\end{tabular}

The survey revealed several tendencies. First of all, the students admitted that communicative learning is the most efficient teaching method, however in their practice it was seldom used, in most cases it was traditional methodology based on reading and grammar skills development. As a result, more than half of the students cannot speak English well enough; in spite of the emphasis on grammar, they admitted many problems in this area. This is, probably, due to the fact that the best way to master grammar is to learn the rule in communication, not in isolation. Secondly, there is an interesting contrariety between the choice of the preferable and the most efficient atmosphere in class. Almost half of the students prefer calm, quiet and predictable atmosphere in class, but only $22 \%$ choose it as the most productive. The rest admit that competitive and imitating professional activity classes give better results. Finally, the majority of students name communication (both everyday and professional) as the most desired outcome of learning English in the university. All these results helped to work out an original integrated approach in teaching English to Bachelor students of the USUE (Fig1). 


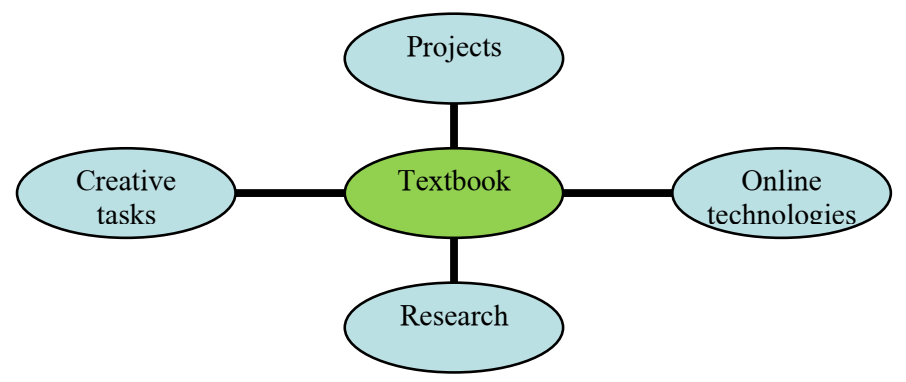

Fig. 1. Integrated approach to teaching English

\subsection{Discussion}

\subsubsection{Textbook}

We choose a textbook as the first and basic element for this approach as "a textbook is a model, in the sense that it does not only reflect the structure of a given didactic system, but it also plans its fulfillment" [6]. In other words, a textbook makes the learning program clear and predictable for the students and thus relieves them of unnecessary stress. We use a traditional printed (paper) textbook "English (for 1st year students) Part 1" [7]. It is a systemized course aimed at oral and written speaking skills development for students majoring in "Economics", "Management", "Computer Science", "HR Management". It has 10 units on different topics relevant for the students. However it seems that professionoriented content might be emphasized more specifically. Insufficient professional bias of the textbook materials made us work out the integrated approach we describe in this paper. Let us agree with D. Gak "teachers should use the textbook as a resource for students, but not the only resource; use a textbook as a guide, be free to modify, evaluate, develop, change, eliminate, or add to the material in the textbook, supplement the textbook with lots of outside readings" [8].

\subsubsection{Multi-university projects}

In 2019-2020 students of USUE took part in the Project "Modeling a Foreign-Language Environment" worked out in Petrozavodsk State University by Department of Foreign Languages for the Humanities. The main goal of the project is to stimulate students of nonlinguistic specialties to the use of English for academic and professional purposes in communication with students from other departments and/or universities [9]. These are some of its stages: 1) Digital Storytelling "My University. My Specialty" is based on the idea of traditional storytelling in English presented with the help of digital tools. The final product is a digital film combining audio text, captions, video, computer graphic, music, etc. The results of students' participation in the Digital Storytelling competition have been described [10]; 2) Translation Contest. Modern students use online translators a lot, the goal of this stage is to teach them correct the Russian translation of an English text made by an online translator. The students had to make the Russian translation of the text grammatically and stylistically correct. This exercise teaches students to identify word-forword translation and replace it by the proper variant in Russian. For instance "structured help" translated as "strukturirovannaya pomoshch" or "raise awareness and money" cannot be translated as "povysit' osvedomlennost' I den'gi", etc.; 3) Listening Comprehension Olympiad "A Video lecture on professional topic" acquaints students with the language of 
science. They practice to make notes of the most essential information, to look for the right word on the basis of its phonetic variant, to listen to the keywords that help them understand the whole sentence, etc. However the students admitted this task to be very difficult due to the tempo of speech, abundance of new words and complexity of the topic discussed. The notes taken by the students took part in the contest in Petrozavodsk State University. This stage of the project served as the basis for students' research work.

\subsubsection{Research}

Scientific work, as many professionals believe, is important to have a successful career. Junior students have underdeveloped skills of scientific and research work, which they can improve by reading and publishing papers in English. In 2019 students were given an opportunity to take part in The III International Scientific Contest among Students "Russia in the Global World: Challenges of the XXI century" held in USUE. More than ten students from the group took an active part in this work, the others learnt the theory of scientific writing and did exercises in class. Three students published their scientific papers in English in the conference proceedings. Their topics were "Cryptographic Algorithms", "Past and Future of the Operating Systems", "Mobile Health Apps: Innovations and Challenges". In future this work will be activated to involve more students and to have more papers published.

\subsubsection{Online technologies}

Today there are numerous web-sites and platforms to make learning more interesting. Due to the fact that many students want to develop their vocabulary skills, we focused on the use of two platforms: 1) "Quizlet" is helpful in learning new words in a foreign language. The idea of the task is that a student creates an account and makes modules with the words they need to learn. We recommend choosing ten to fifteen words from glossary for one module, otherwise each step will take too much time. When the module is ready, a student has to learn the words with the help of Flashcards (click a word and its translation is shown), Memorizing (write a word in English), Spelling (spell the word looking at a picture), etc. Students created their own modules with words and learned them, exchanged their modules and learned other words. Based on the students' comments, this way of learning new words is very quick and efficient; 2) "Kahoot" is a game-based learning platform that helps to check how well students learned the material in a form of a contest. We used it primarily to check vocabulary in class, when students had to answer the questions as fast as they could. In the end, their rating was shown on the screen, which stimulated them to do better.

\subsubsection{Creative tasks}

Creative task is an important element of this integrated approach, as it helps students to relieve stress, overcome fear of speaking, express themselves and combine language skills with creative thinking. In our opinion, multimodal teaching should exceed the traditional use of pictures in textbooks, audios and videos. Students should become the authors of these multimodal products, thus they will be able to activate different perception channels more efficiently. Creative tasks were introduced in class approximately once a month, the following tasks were the most successful: "A concept of a unique hotel" - when students were asked to draw a poster to advertise their hotel (both teams came up with vegetablebased ideas of a hotel) and anti-smoking posters (Fig.2.), poetry contest (students wrote poems in English with the words or grammar rules studied), drawing and sketching on the whiteboard, riddles and jigsaw puzzle. 

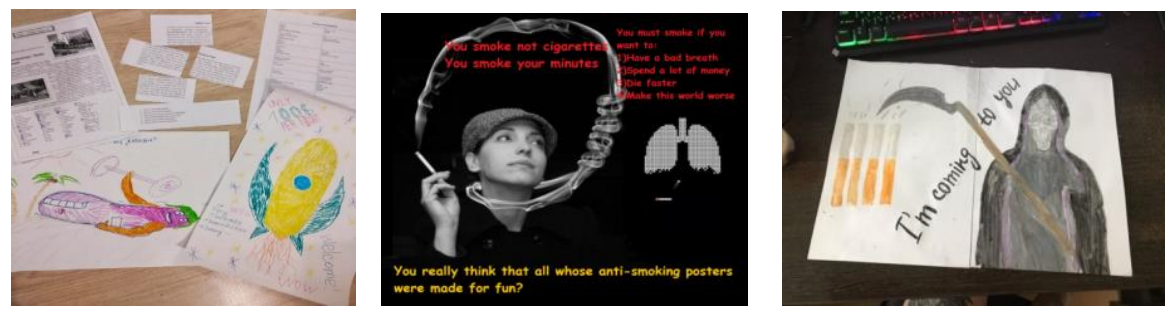

Fig. 2. Unique hotel and anti-smoking posters

\section{Conclusion}

This integrated approach to teaching English has the following advantages: 1) professional focus (students learn to speak about their profession and enrich professional vocabulary); 2) competitive atmosphere (many students got rid of the fear to take part in the contests in the foreign language; integrated approach to teaching helped five students win in different allRussia contests (within the multi-university project), three students' papers were published in scientific journals); 3) emphasis on communication (students communicate not only with each other and their teacher, but also with students from other universities); 4) digital technologies (online tools in English classes aroused more interest to the subject); 5) psychological relief (creative tasks helped to get rid of fear to speak English). So, higher education should provide every student with an opportunity for personal growth, we must introduce new complex approaches to teaching and adapt to students' needs.

\section{Acknowledgements}

The reported study was funded by the Russian Foundation for Basic Research, project number 19-013-00895 "Learning to Understand Russia: Cognitive Strategies of Teaching Aids in Russian as a Foreign Language".

\section{References}

1. P.S. Norkina, O.I. Taranenko, Bul. Adyghe State Uni. Ped and Psy., 1 (2015)

2. K.M. Inozemtseva, Educ. and Sc. J., 19 (2017)

3. L.G. Mudrova, Ling. Mobilis, 2 (48) (2014)

4. O.N. Goroshko, A.A. Maigov, Sc.and Modernity, 29 (2014)

5. C. Rogers, H.C. Lyon, R. Tausch, London: Routledge (2013)

6. A.V. Khutorskoy, Pedagody, 4 (2005)

7. E.N. Makarova, I.V. Pervukhina, English (for $1^{\text {st }}$ year students) Part I: textbook (2018)

8. D. Gak, Textbook - An Important Element in the Teaching Process (2011)

9. I.E. Abramova, E.P. Shishmolina, Ed. Studies, 3 (2017)

10. E.N. Makarova, I.S. Pirozhkova, DETP (2020) 